\title{
The Role of Landscape Architecture Profession In Two Different Contexts: \\ A Comparative Review of the Practitioners in Responding To Climate Change Adaptation
}

\author{
Submitted: 4 March 2014 \\ Accepted: 12 July 2014 \\ Irina Mildawani ${ }^{1}$, Shahed Khan ${ }^{2}$ \\ ${ }^{1,2}$ Department of Urban and Regional Planning, Curtin University, Perth, Western Australia ${ }^{1}$ \\ ${ }^{1}$ irina.mildawani@curtin.edu.au
}

\begin{abstract}
In the context of rising concerns about global warming and sustainable development this paper examines the challenges of landscape architecture (LA) in developing and developed countries in handling climate change adaptation. The paper aims to find how the LA institutes define their professionals' roles in dealing with society and environment. It seeks to focus on the professionals' involvement in climate change adaptation programs in Indonesia and Australia. The paper seeks to determine how contextual factors such as institutional roles and types of prevalent governance systems shape the development of landscape architecture discipline and its professional capability with respect to other related built environment professions (architecture and planning). The websites of the ISLA (Indonesian Society of Landscape Architects) and the AILA (Australian Institutes of Landscape Architects) are examined and analysed from the perspective of professional principles of the International Federation of Landscape Architects (IFLA). The aim is to determine the LA practitioners' awareness and approaches in handling climate change challenges in various roles and capabilities. It has found that the professional institute in Australia has been involved in the educational program to equip their practitioner members to have a basic knowledge and further application of climate change adaptation in their design and planning projects; whereas in Indonesia the practitioners are actively involved in community capacity building to increase people's awareness and participation in mitigating the climate change at local as well as regional levels. Findings from the study seek to establish the universality of the LA profession and its relevance in both developed and developing countries.
\end{abstract}

Keywords: climate change adaptation network, IFLA principles, ISLA and AILA, landscape architecture profession

\section{Introduction}

According to the Intergovernmental Panel on Climate Change (IPCC 2007), global warming has impacts that change the context of the human habitat. Accordingly, there is emerging urgent need of built environment professionals to handle climate change challenges and carry on related actions at the urban and regional levels (Habitat, 2011). The urgent need to mitigate and adapt to climate change is becoming more widely understood in scientific and policy circles, but according to Sheppard (2005), public awareness has been left behind. In other words, policy makers and built environment professionals should respond in order to increase community awareness that is still moving slowly even in the developed countries (Sheppard et al., 2008).

There is a huge need (1) to increase awareness and better practice to enhance the sense of urgency, (2) to accelerate professional responses to climate change in developing country, and (3) to review those responses by comparing them with what has happened in the developed country. In this context, this paper investigates the Landscape Architecture (LA) profession's roles and capacities to examine their important roles in (1) urban design and regional planning processes, and (2) community capacity building in Indonesia and Australia. This may accelerate the LA professional advantages in carrying the potential roles and responses in handling climate change adaptation in the form of convincing methods in those two different contexts. Since Landscape Architecture (LA) has an interdisciplinary approach in its discipline, there are a lot of aspects in Landscape Architecture research subjects to review, such as value systems, ecological observations or processes, spatial pattern recognition, or vegetative processes (Boyer, 2003, Whitehand and Larkham, 1992, Kienast et al., 2007).

Recently, however, very little landscape architecture research has been conducted in terms of reviewing its own professional development as a discipline, especially in the area of LA practices. In 2000, Thompson used a discourse analysis approach to review the ethical and aesthetic values held by 
landscape architecture professionals who had been in practice in the UK for a minimum of ten years (Thompson, 2000a). On the other hand, Crewe and Forsyth (2003) studied the application of the design approaches by landscape architecture professionals to their projects, which they defined as acronym of "LandSCAPES". There have been fewer studies undertaken with regard to the role of the LA profession and its position among other Built Environment (BE) professions. This paper aims to examine the LA profession in responding to the social and environmental problems, particularly in handling climate change mitigation and adaptation.

\subsection{Principles and Practices as a role model}

During the last two decades we have seen emerging literature on architectural, planning and landscape architecture in related topics of sustainable development as well as global warming and climate change adaptation. As computer-aided-design (CAD) penetrates the design and planning disciplines, the built environment professions have a great advantage in using it in their practice. The advanced tool of landscape visualization turns out to be useful in communicating the improved landscape condition to the general public. The images of future low-carbon-conditions of certain sites, which are more easily presented to people with the landscape visualisation approach (see Fig.1), are also very useful in educating people and enhancing their awareness and subsequent motivation to participate in the climate change adaptation movement (Sheppard, 2005, Sheppard, 2012).

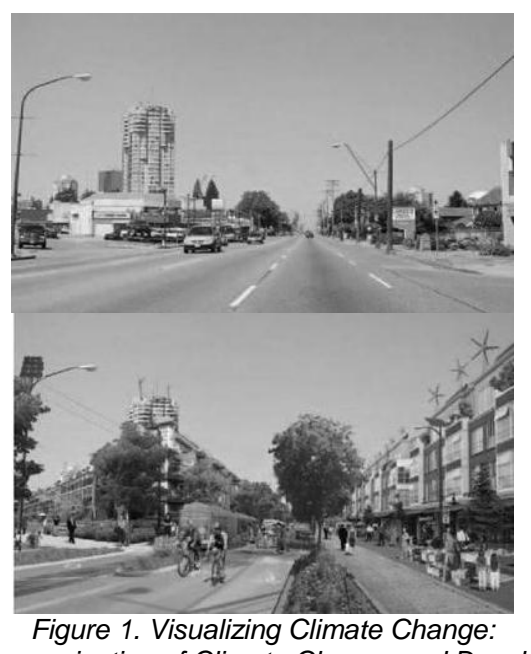

A Guide to Visual Communication of Climate Change and Developing Local Solutions (Sheppard, 2012)

\subsection{Governmental Practice as a role model}

Principles for adaptation have been proposed at various scales involving many prominent countries that have made a commitment to handle climate change mitigation (Wilson and Piper, 2010). The reputable London Plan Review was forwarded by the Mayor-of-London (2005) which was then followed by a more detailed guidance called London Plan policy in 2008 (Mayor-of-London, 2008) that can be accessed by the public through the City of London website. The website which is titled "Re-Think of London" has many interesting features on urban planning and design to educate the public and show how the government has transparency in handling climate change adaptation and mitigation in metropolitan London that has been involving experts and the community. This evidence is a respectable model of public education created by the government in co-operation with the experts for the general public in an open access web page. Such a strategic action plan can be adopted by the Indonesian government as well as the Professional Institutions that are charged to respond to climate change mitigation and adaptation.

\subsection{Transnational Networks and Climate Change}

Since the climate change adaptation network is an issue of concern not only for the international and national agendas, it involves a range of transnational networks (Bulkeley and Newell, 2010). The Indonesian government has been forwarding the actions toward climate change mitigation and adaptation since the UNFCCC COP 13 in Bali, Indonesia, December 2007, which declared two important decisions on (1) Bali Action and (2) the REDD+ (Reducing Emissions from Deforestation and Forest Degradation). The purpose is to build a global network to mitigate climate change by compensating the carbon price for developing countries in protecting and replanting their forests (RI, REDD-I Newsletter,Edisi1-1, Ags2011). However there is no significant or potential role for either LA practitioner or researcher involved in the Indonesian government/delegation as representative for the climate change adaptation network. Several examples of activity schemes in transnational governance can be applied as potential schemes of cooperation between the Indonesian and Australian governments at the regional scales: (1) information sharing (The Climate Group Principles); (2) implementation and capacity building (the Renewable Energy and Energy Efficiency Partnership) and (3) regulation (the Regional Greenhouse Gas Initiative) (Bulkeley and Newell, 2010) 


\section{The Landscape Architecture (LA) Professional Stance towards Climate Change 2.1 Evidence from the previous studies}

These decades have been witnessing the importance of awareness and co-operation of interdisciplinary professionals in handling the universal issues such as global warming and climate change. In the process of policy-making and action plans for climate change adaptation and mitigation, it is important that landscape architects perceive their roles and responsibilities in communicating the impact of climate change and how people can do their parts to avoid the worse impact. However, for many people and communities, climate change adaptation is a vague problem and not yet clearly perceived as one of their personal or community problems. In order to perform the landscape architecture professional approach, there has been an advanced research based on design system called "research-through-designing" (RTD) as termed by Lenzholzer et al. (2013). Several LA practitioners as well as LA academics have conducted such "computer-aided-visualisation" approach which supports to bridge the gap between an abstract concept and everyday experience. This technique is a promising approach to engage different groups' interests in society. The RTD studies has a wide range of activities, from the examination and visualization of local climate change to the visualisation of future possibilities of urban landscape schemes and designs for a better environment to increase people's awareness of climate change (Sheppard, 2005). It is also hoped that this approach will generate the possibility of affecting behaviour and policy (Nicholson-Cole, 2004); as well as assisting decision-making at the local level (Dockerty et al., 2004). Nevertheless, the visual approach of design communication to generate the future image of low-carbonconditions for sustainable urban development is still arguable in terms of its ethics and potential for influencing people's perceptions and behaviour (Sheppard et al., 2008, Nicholson-Cole, 2004, Pielke Jr., 2005).

This paper, however, will explore the LA practitioners' awareness, perceptions, and concept of future professional roles and responsibilities to handle climate change adaptation. By examining the professional institutes' websites, documents and other related information of the ISLA (Indonesian Society of Landscape Architects) and the AILA (Australian Institutes of Landscape Architects); and analysing them with reference to the perspective of professional principles of the International Federation of Landscape Architecture (IFLA), this study aims to find to what extent the evidence of LA professional institutes, LA professional counter-partnership (with government systems as well as LA initiatives in private practice and community capacity building) in handling the challenges of climate change adaptation.

\subsection{The Professional Ethics of Landscape Architecture set by the IFLA}

Based on the definition of the LA profession in the International Standard Classification of Occupations, International Labour Office, Geneva: the occupations of LA professional is defined as: "landscape architects research, plan, design and advise on the stewardship, conservation and sustainability of development of the environment and spaces, both within and beyond the built environment" (IFLA, 2010). In order to accomplish the professional role and responsibility effectively, the LA profession needs to perform professionalization through credentialing processes. Therefore it is important to review the role of professional ethics in LA practice, in comparison with the Code of Ethics, which is a set of professional principles set by the International Federation of Landscape Architects (IFLA, 2012). Having historically been responsive to contextual social and environmental issues, the fundamental position of Landscape Architecture is associated with the nature stewardship -- as stated in IFLA's principle (IFLA, 2012) -- 'to protect and enhance the relationships between nature and human welfare'. The third Code of Ethics of the IFLA (International Federation of Landscape Architects) states the organisation's position toward landscape and environment as: (1) to recognize and protect the cultural and historical context and the ecosystem to which the landscape belongs when generating design, planning and management proposals, (2) to develop, use and specify materials, products and processes which exemplify the principles of sustainable management and landscape regeneration (Heritage, 2009), (3) to advocate values that support human health, environmental protection and biodiversity.

Referring to the above IFLA principles, the LA profession consequently has a great responsibility in handling the Climate Change adaptation network in their various scales of projects: urban and regional planning and designing for the best values of human wellbeing. In order to communicate their proposal planning and design of a better future condition of human habitat and environment, it is a must that the LA profession uses language that is clear and understandable for a general audience. Therefore the promotion of landscape visualisation to represent the image of future conditions while climate change is happening and its impact to the urban environment will be a supportive and beneficial tool for the public to enhance their awareness and increasing their willingness to participate in climate change mitigation and adaptation.

\subsection{The Ethics and Values Inherent in the Role and Responsibilities of LA Professionals}

In order to examine the LA professional role and responsibility, it is important to investigate a framework for understanding the value systems inherent in the LA practice. Ian Thompson suggested a value system of ethics inherent in LA practice as one of the Environmental Design Professions. He suggests that there are three Ethics to possess for LA practitioners to be successful, including: (1) personal ethic, (2) business proprietary, and (3) a trivalent value of professional ethics (Thompson, 2000b). 
In reviewing the LA practitioners roles and capacities based on the IFLA's principles, this study adopts the trivalent value systems of LA practice to accomplish their projects. Among the ethics elements suggested by Thompson (2002) this paper will focus on the Ecological Values, whereas the other systems are also incorporated in order to pursue the study on climate change adaptation and mitigation. See the Figure2. Professional Ethics of Landscape Architecture.

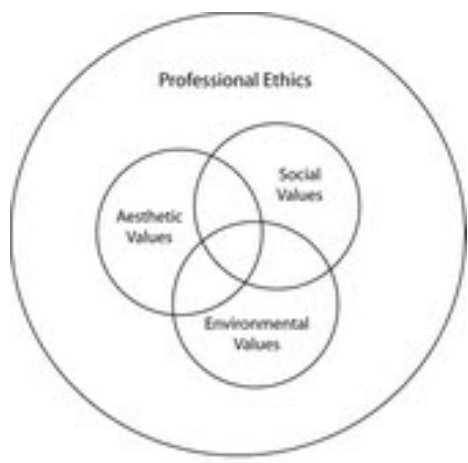

Figure 2. Professional Ethics in Landscape Architecture, (adopted from Thompson (2000a)

\subsection{The Role and Responsibilities of LA Professional Institutes}

There are several professional groups of landscape architects in Indonesia, including the IALI (Ikatan Arsitek Lansekap Indonesia) and AKLANI (Asosiasi Kontraktor Lansekap Indonesia). However, only one is registered as the Indonesian LA professional organisation member at the International Federation of Landscape Architects (IFLA), that is the Indonesian Society of Landscape Architects (ISLA) or known as Ikatan Arsitek Lansekap Indonesia (IALI). Being founded in 1978 (IALI, 2012), the Indonesian Society of Landscape Architects as a professional organisation has around 500 individual practice members. This paper begins with a qualitative explorative study on line upon a website mailing list of the professional organization of the Indonesian Society of Landscape Architects (ISLA) or Ikatan Arsitek Lansekap Indonesia (IALI) - Asosiasi Kontraktor Lansekap Indonesia (AKLANI). Both organizations have a website mailing list in Facebook known as IALI-AKLANI. This website was constructed by the ISLA Council members to accommodate the communication among the members to share their needs, ideas and professional experiences. The fact is that the institute's members are busy people with tight schedules and it is difficult for the professionals to find time to meet each other to share ideas or experience in order to keep up with the pace of their projects in landscape developments. This online media turns out to be very effective and beneficial for the LA professional members to communicate with each other both professionally as well as privately. Figure3 shows the proportion of ISLA profile members (IALI, 2010a).

The typology of LA professional jobs in Indonesia is: predominantly (27\%) work for neighbourhood parks, followed by urban and regional planning $(25 \%)$. The professionals' activity in site planning shows a smaller proportion of practitioners do that activity (14\%), whereas landscape construction management is only $12 \%$. The least proportion is the number of landscape architects who are involved in education (8\%), which is crucial as this function is very important in order to keep the professional sustainability for the future. The other job that is seldom recognised yet is imperative in increasing the profession's recognition as a discipline is the editor of landscape publications (5\%) (IALI, 2010a).

Meanwhile, the Australian Institute of Landscape Architects (AILA, March 2005) is the only recognised professional body for landscape architects in Australia.

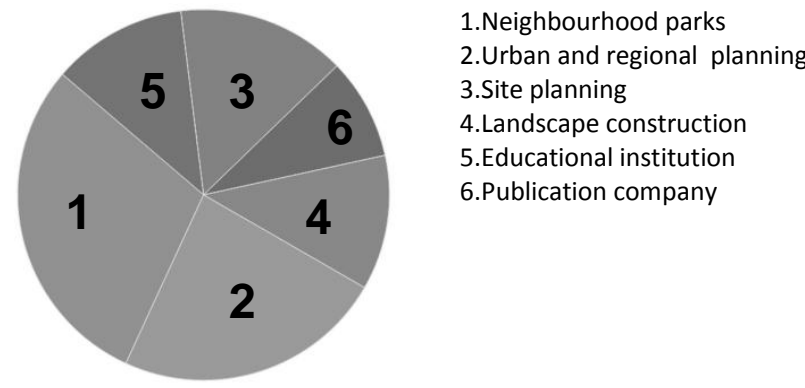

Figure 3. Typology of landscape architecture projects and relevant jobs of the landscape architecture profession in Indonesia

$$
\text { (IALI, 2010a) }
$$

The AILA has profile members indicating that the professionals are working in various activities such as planning and analysis activity $(25 \%)$, which is the most preferred scale of job, followed by design (24\%). Other roles of landscape architects which are significant to support the initiatives between the 
profession and the stake holders in handling the climate change adaptation are: classified as shaping community (15\%) and environmental stewardship (15\%). The least preferred jobs of people with landscape architecture backgrounds are: construction and craftsmanship (13\%) and collaboration (8\%), based on a source from: AILA (2000). See Figure 4. Typology of LA projects and relevant jobs of the LA profession in Australia (Johnston, 2010).

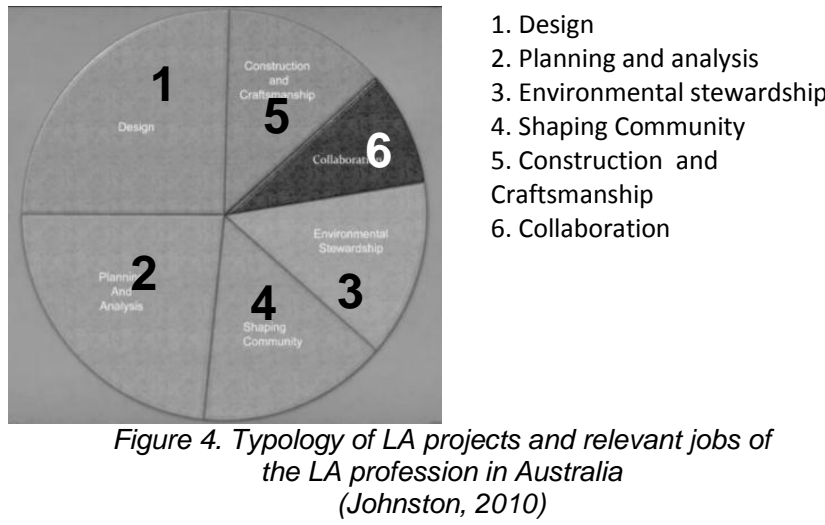

Looking at both Institutes' profiles of members, we can see a similar proportional segmentation with each has different attributes. In Indonesia most of the ISLA members are classified as working at the neighbourhood scale (in designing neighbourhood park/and involved in its construction), while in Australia most of the AILA professionals are involved in planning and analysis projects, followed by almost the same segmented proportion of professionals involved in design.

\subsection{The Institutes Role in Education and Setting the Standard of Professional Practice in Spatial Planning and Design in Handling Climate Change Adaptation}

Referring to the IFLA's principles of professional practice, the national institute of LA Profession in Indonesia (ISLA) and in Australia (AILA), have a professional responsibility in handling the climate change mitigation and adaptation. How the Professional Institutes in both countries adopt these responsibilities in their practice is to be reviewed in this paper. From the AILA website, it is clear that this institute has already set a national policy: (1) to advance the profession of Landscape Architecture in the service of the public interest, and (2) to provide leadership in the creation and stewardship of sustainable cities and settlements (AILA, March 2005); whereas the ISLA has stated their vision and mission: (1) to build and develop landscape architecture professionals who are trusting and faithful to the Al-Mighty God, [who] are ethical and noble-minded and have environmental awareness, and (2) to be actively participating in Indonesian's [national] sustainable development. The ISLA missions are: (1) to grow and develop public awareness and appreciation to the landscape architecture profession, (2) to encourage and actively promote the creation of cultural and natural environments in landscape architectural projects that are high quality and are safe, healthy, green and sustainable, (3) to improve the quality and competitiveness, as well as protecting Indonesian landscape architects in carrying out their professional duties, in relation with their peers of other built environment professions, user-clients as well as community and government and (4) to support the development of landscape architectural education to produce a young generation of landscape architects who are creative, capable, entrepreneurship-oriented and environmentally aware (IALI, 2010b).

These statements (which have been translated by the researcher from the IALI vision and missions as stated in the website).reflect a growing profession which is not yet fully established in the minds of the public. With such statement of vision and missions, the ISLA obviously has adopted awareness toward climate change adaptation and has planned to educate its members to apply this matter in daily practice. However there is no evidence of any structured programs uploaded to its website to equip its professional members with basic knowledge and skills to handle climate change adaptation in LA projects.

On the other hand, AILA has already stated strategic plans and programs: (1) Climate Adaptation Tools for Sustainable Settlements 2009-2010, which has been accomplished in partnership with IFLA and the CSIRO, with the purpose "to preliminary review the Australian and international examples of climate adaptation tools and strategies for responding to the impacts of climate change within the context of the built environment;; (2) Climate Change Adaptation Skills for Professionals Program 2008-2011, with purpose "to integrate understanding of the implications of climate change into education and training for professionals involved in developing planned adaptive responses to the impacts of climate change" (AILA, 2000). By reviewing the AILA website, it is clear that the institute has been developing and implementing the LA professional development programs to increase the expertise of landscape architects in assisting their clients and governments to develop adaptive responses to climate change impacts. This complies with the AILA vision and mission statement that is [to achieve]: "resilient, engaging and healthy urban, regional and rural environments, designed in balance with natural and cultural systems", 


\section{Climate Change Governance}

\subsection{The Government Role and Action involving the Community}

Despite the perceived importance of public participation's role in climate change network, Bulkeley and Newell (2010) mentioned that there are barriers to engaging the public, that on one hand include: (1) individual barriers, which concern: lack of knowledge, uncertainty and scepticism, distrust in information of sources; and on the other hand include: (2) social barriers, which include: lack of actions by governments, business and industry, lack of enabling activities and pressure of social norms and expectations.

To overcome these barriers to engaging the public in participating in climate change adaptation and mitigation, it is necessary that the government as well as the experts (professional institutes and NGOs) give a hand to educate people in terms of community capacity building. The Indonesian government has been aware of this responsibility and annually holds a national event of the Indonesia Climate Change Education Forum \& Expo; which this year is the $3^{\text {rd }}$ event with a theme on: Working Together Saving Tomorrow Today. The event was held on 18-21 April 2013 in Jakarta Convention Center in order to exchange information among the governmental institutions and scholars about the climate change strategic steps on mitigation and adaptation technologies in the educational forum and approaches for community capacity building.

To complement the government's role and policy, it is essential that the expert group (such as LA practitioners) is involved in the community empowerment to enhance public awareness and participation in climate change mitigation and adaptation as mentioned above.

\subsection{The Community Role in Climate Change adaptation networks}

Looking at the initiative actions in private sectors in Indonesia, we can mention several NGOs that actively are engaged in the community capacity building programs in various local and even in some remote areas. Several Indonesian NGOs significantly claim to be actively involved in the climate change adaptation and mitigation movement, including Jaringan Aksi Karbon Indonesia shortened as JAKI or also known as the Indonesian Carbon Action Network, shortened as ICAN, in which members also call themselves "Laskar Iklim" (the Climate Warriors). There have been many actions accomplished under the scheme of sustainable development and climate change adaptation network. Their activities including educating people (community capacity building) to increase people awareness in responding to the climate change adaptation, cleaning and planting the coastal areas with some mangroves species in order to counter coastal erosion. In the private education sector, this group of NGOs was actively involved in community activities such as seminar, workshops, story-telling for children, green community competition, tutorial on environmental knowledge and practice for young generation.

Although Indonesia witnesses many NGOs that are involved actively in sustainable development programs, this paper focuses only on the ICAN (JAKI) activities, because: (1) this NGO's founder and principal members are also the ISLA members, and (2) this NGO has been focusing its activities on handling climate change mitigation and adaptation. See Figure 5 to view the activities and icon of this NGO of the "Climate Warriors", a title as the members claim themselves (JAKI, 2012).
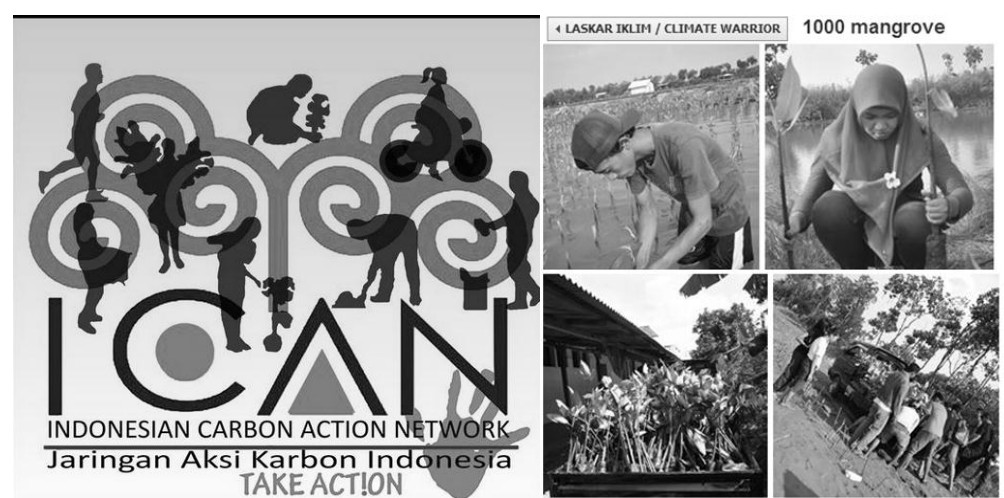

Figure 5. The Indonesian Carbon Action Network (ICAN) and its members actively involved in replanting 1000 mangroves along northern coastal áreas of Java Island

(JAKI, 2012).

The grassroots movement was also indicated in the landscape of the climate change adaptation network in Australia (Burgmann and Baer, 2012). The presence and rapid growth of the NGOs focusing on Climate Change adaptation and mitigation signified the emergence of climate politics from below in Australia by the time the Grassroots Movement started around the 1980s. Furtherly, Burgmann and Baer (2012) stated that this situation indicates that the government's reluctance to make the tough decisions necessary to mitigate climate change, has triggered the emergence of these organizations. Unfortunately, there is no evidence in literature nor in the website about the co-relation between these environmentalists and the membership of the LA Institute in Australia. Hence this paper will not discuss it any further. 


\section{Conclusion}

\subsection{Professional institutions}

In spite of the practice evidence of its members in relation to the government and private sectors, in several national and international projects, as well as maintaining the relationship with educational institutions and community activities, the ISLA (Indonesian Society of Landscape Architects) website has not provided convincing evidence of professional and educational programs for its members in handling Climate Change adaptation. On the other hand, the AILA (Australian Institute of Landscape Architects) has shown convincing evidence of its capabilities through the professional institute website which shows organized and structured professional modules to educate its members to become equipped with the skills and knowledge needed for LA practitioners to handle the Climate Change adaptation and mitigation.

\subsection{NGO initiatives to support the LA Institutes}

Based on the policy to implement the landscape architecture principles as stated by IFLA, several members of the ISLA have forged another path of executing the Climate Change adaptation through NGO activities and lead professional participation in community capacity building. These NGO activities may be bound to national government programs in Indonesia as well as part of international initiatives and funding. In Australia there are also similar NGO initiatives in addition to the professional institutes' task forces and structured program of implementation. Particularly these NGOs of climate change adaptation network are bound by the government and international framework of climate change adaptation network, but there has been no evidence nor it is clearly defined whether the NGO's members are also members of the AILA.

\subsection{The Government's role and responsibility}

Both the Indonesian and Australian governments have been bound to the Interngovernmental Panel on Climate Change (IPCC2007). Responses to climate change in Indonesia and Australia have shown evidence of recent government initiatives at national, regional and local levels. However, these initiatives are to some extent only happening in the last couple of years as an introductory awareness or an initial effort to open people's attention and understanding. As the climate change challenges have been occurring rapidly and globally with particularly severe impacts in both countries through events such as floods, droughts, storms and tsunamis, we need to address this matter in more intensive and enhanced ways through regional network adaptation and cooperation in advance technology and expertise. Landscape architecture expertise is one of the most relevant professions with regard to being involved in this matter.

\section{Acknowledgement}

The researcher (first author) would like to appreciate the Dikti (Indonesian government) and Gunadarma University as being the scholarship sponsors and Curtin University as the institution that allows me to follow my journey as a doctoral degree student in Urban and Regional Planning. Also to other parties who have contributed to the study and for supporting the conference attendance. This arcticle has been presented at the International Conference of Regional Development on 20-21 November 2013 (ICRD 2013) in Semarang, Indonesia and published in the ICRD 2013 Proceeding. With some revisions, this article is submitted to the Indonesian Journal of Planning and Development on 3rd of March 2014.

\section{References}

AILA 2000. LANDSCAPE ARCHITECTURE: the Passionate Profession. www.aila.org.

AILA. March 2005. AUSTRALIAN INSTITUTE OF LANDSCAPE ARCHITECTS [Online]. [Accessed 23 July 2013.

BULKELEY, H. \& NEWELL, P. (eds.) 2010. Governing Climate Change, London and New York: Routledge Taylor and Francis Group.

BURGMANN, V. \& BAER, H. A. 2012. Part III: Climate Politics from Below: the Grassroots Movement. Climate Politics and the Climate Movement in Australia. Melbourne, Victoria, Australia: Melbourne University Press.

CREWE, K. \& FORSYTH, A. 2003. LandSCAPES: a Typology of Approaches to Landscape Architecture. Landscape Journal, 22.

DOCKERTY, T., LOVETT, A., SUENNENBERG, G., APPLETON, K. \& PARRY, M. 2004. Visualising the potential impacts of climate change on rural landscapes. Computers, Environment and Urban Systems, 29, 297-320.

HABITAT, U. 2011. Cities and Climate Change: Global Report on Human Settlements 2011. London and Washington, DC.: United Nations Human Settlements Programme (UN-Habitat).

HERITAGE, T. A. 2009. Dictionary of the English Language Dictionary of the English Language 4th ed. USA.

IALI 2010a. IALI Member Profile Jakarta, Indonesia: IALI.

IALI. 2010b. Vision and Mission [Online]. Jakarta, Indonesia: IALI - the Secretariate of National Council. [Accessed 14 January 2013 2013]. 
IALI. 2012. History of the ISLA (Indonesian Society of Landscape Architects) [Online]. Jakarta, Indonesia: ISLA (The Indonesian Society of Landscape Architects). Available: www.landscape-isla.org [Accessed 18 October 2013].

IFLA. 2010. Landscape Architecture professional scope of job and responsibility [Online]. Geneva: IFLA. [Accessed 14 January 2013 2013].

IFLA. 2012. IFLA Code of Ethics [Online]. The International Federation of Landscape Architects. Available: http://www.iflaonline.org/images/PDF/Homepage/iflacodeofethics.pdf [Accessed 17 July 2012.

JAKI, I.-. 2012. Climate Warrior [Online]. Jakarta, Indonesia: Indonesian Carbon Action Network (ICAN). Available: https://www.facebook.com/groups/142598465808373/ [Accessed 18 September 2013 2013].

JOHNSTON, J. L. 2010. Why Landscape Architecture 2010?

LENZHOLZER, S., DUCHHART, I. \& KOH, J. 2013. "Research through designing" in landscape architecture. Landscape and Urban Planning, 113, 120-127.

MAYOR-OF-LONDON 2005. On ReThink London. London, UK: Clty of London.

MAYOR-OF-LONDON. 2008. London Plan policy [Online]. London, UK: City of London. Available: http://rethinklondon.ca/events/past [Accessed 5 November 2013 2013].

NICHOLSON-COLE, S. A. 2004. Representing climate change futures: a critique on the use of images for visual communication. Computers, Environment and Urban Systems, 29, 255-273.

PIELKE JR., R. A. 2005. Misdefining "climate change": consequences fro science and action. Environmental Science \& Policy, 8, 548-561.

RI, B. H. REDD-I Newsletter,Edisi1-1, Ags2011. Hutan dan Perubahan Iklim di Indonesia (Forest and Climate Change in Indonesia) [Online]. Bogor, Indonesia: Balitbang Hutan RI. Available: http://www.redd-indonesia.org/tentang-kami/situs-web-redd-i [Accessed 12 December 2012 2012].

SHEPPARD, S. R. J. 2005. Landscape visualisation and climate change: the potential for influencing perceptions and behaviour. Environmental Science \& Policy, Volume 8, Pages 637-654.

SHEPPARD, S. R. J. 2012. Visualizing Climate Change: A Guide to Visual Communication of Climate Change and Developing Local Solutions. London and New York: Hoboken : Taylor and Francis

SHEPPARD, S. R. J., SHAW, A., FLANDERS, D. \& BURCH, S. 2008. Can Visualisation Save the World? - Lessons for Landscape Architects from Visualizing Local Climate Change Landscape Architecture [Online]. Available: http://193.25.34.143/landschaftsinformatik4.2.6/fileadmin/user upload/ temp /2008/2008 Beitraege/001/Buh 2-21.pdf [Accessed 22 October 2013].

THOMPSON, I. 2000a. Aesthestic, Social and Ecological Values in Landscape Architecture: a Discourse Analysis. Ethics, Place and Environment, 3, 269-287.

THOMPSON, I. 2000b. Sources of Values in the Environmental Design Professions: the Case of Landscape Architecture. Ethics, Place and Environment, 3, 203-219.

THOMPSON, I. H. 2002. Ecology, community and delight: a trivalent approach to landscape education. Landscape and Urban Planning, 60, 81-93.

WILSON, E. \& PIPER, J. (eds.) 2010. Spatial Planning and Climate Change, London and New York: Routledge Taylor and Francis Group. 